\title{
PEDAGOGICAL PRACTICES ADOPTED BY TEACHERS WHEN USING IMPROVISED RESOURCES IN LIFE SCIENCES CLASSROOMS
}

\author{
Syamthanda Zondi, \& Sam Ramaila \\ Department of Science and Technology Education, University of Johannesburg (South Africa)
}

\begin{abstract}
Pedagogic innovation is central to meaningful enhancement of human capital development. Concerted efforts geared towards meaningful science teaching and learning hinge to a large degree on a myriad of crucial factors which serve as key ingredients for creating a conducive environment within which envisaged learning outcomes can fruitfully be realized. In recognition of this key strategic imperative, the study explored pedagogical practices adopted by teachers when using improvised resources in Life Sciences classrooms at South African township schools. The study adopted a case study design located within the interpretive research paradigm. Data was collected through semi-structured interviews and lesson observations involving three purposively selected Life Sciences teachers. The cohort of teachers observed employed various pedagogic strategies such as inquiry-based learning, collaborative learning, cooperative learning as well as heuristic learning when using improvised resources to stimulate effective teaching and learning in Life Sciences classrooms. However, the selection and deployment of appropriate improvised resources proved to be an arduous task for the teachers although they fully acknowledged the significance of integrating improvised resources in science lessons. In addition, meaningful opportunities for harnessing learners' prior knowledge as a scaffold for navigating new content were created. Implications for pedagogic innovation are discussed.
\end{abstract}

Keywords: Pedagogical practices, improvisation, pedagogic innovation.

\section{Introduction}

Pedagogic innovation is central to meaningful science teaching and learning. The provision of science instruction in resource-constrained environments is a pervasive fundamental challenge facing teachers in South African township schools. While considerable emphasis has been placed on the adoption of contemporary pedagogic approaches such as inquiry-based learning to foster meaningful science teaching and learning, adequate attention ought to be devoted to continuous professional development of teachers on the coherent implementation of these innovative pedagogic approaches. Demystifying abstract scientific concepts remains an arduous task for teachers and this professional challenge places an added pedagogic burden on teachers to adopt innovative pedagogic approaches to enhance meaningful learner conceptual understanding within resource-constrained environments. According to Driscoll (2005), understanding occurs when students actively relate new concepts to their existing knowledge. Progressive realization of this goal requires teachers as key agents of educational change to fully embrace learner-centered instructional approaches. McCombs and Whisler (1997) define a learner-centered model as a perspective that couples a focus on individual learners with a focus on learning. Pervasive fundamental challenges afflicting the provision of science instruction in resource-constrained environments underscores the need to use improvised resources in science teaching and learning. Hence, the study explored pedagogical practices adopted by teachers when using improvised resources in Life Sciences classrooms at South African township schools.

\section{Research design and methodology}

The study explored pedagogical practices adopted by teachers when using improvised resources in Life Sciences classrooms at South African township schools. The study adopted a case study design located within the interpretive research paradigm. Data was collected through semi-structured interviews and lesson observations involving three purposively selected Life Sciences teachers. 


\section{Findings}

The cohort of teachers observed employed various pedagogic strategies such as inquiry-based learning, collaborative learning, cooperative learning as well as heuristic learning when using improvised resources to stimulate effective teaching and learning in Life Sciences classrooms. However, the selection and deployment of appropriate improvised resources proved to be an arduous task for the teachers although they fully acknowledged the significance of integrating improvised resources in science lessons. In addition, teachers created meaningful opportunities for harnessing learners' prior knowledge as a scaffold for navigating new content. The teachers demonstrated inadequate confidence with the implementation of inquiry-based learning in particular. This professional inadequacy calls for provision of sustainable teacher professional development opportunities with a view to enhance teacher professional expertise on the implementation of contemporary pedagogic approaches. The use of improvised resources provided hands-on learning experiences for learners. In addition, learners were afforded opportunities to engage collaboratively and this culminated in the creation of a conducive and collegial learning environment.

When using improvised resources, teachers recognised the need to provide context to learners' realities and existing knowledge as the following excerpt reflects.

Learners become very interested and they learn a lot when they touch and feel the different parts of the heart. You find learners being surprised and wanting to learn more because this is something that they are used to and therefore can relate easily to it.

The teachers demonstrated fundamental appreciation of the pedagogical affordances of cooperative learning. This sentiment is encapsulated in the following excerpt.

It is good when learners do things in groups because they learn from each other. It is always the case with group work, learners think best when they learn as groups.

The teachers displayed some measure of innovation when designing improvised resources to use in Life Sciences classrooms as reflected in the following excerpt.

I would use washing powder to explain how enzymes work. If I want to use an acid, I use Sprite cool drink which is an acid that learners use on a daily basis.

\section{Discussion}

This study demonstrated that teachers employ various pedagogic strategies when using improvised resources to stimulate effective teaching and learning in Life Sciences classrooms. However, the selection and deployment of appropriate improvised resources proved to be an arduous task for the teachers. There is a critical need to provide sustainable teacher professional development opportunities to enhance teacher professional expertise on the integration of improvised resources in science teaching and learning. In addition, teachers ought to be implored to adopt learner-centered approaches in order to realize envisaged curriculum outcomes. Learner-centered approaches provide opportunities to engage and co-construct knowledge in order to experience deep and meaningful learning (Schweisfurth, 2011).

Meaningful integration of improvised resources in science teaching and learning hinges to a large degree on enhanced pedagogical content knowledge. The use of improvised resources provides teachers with opportunities to enhance their pedagogical content knowledge as they actively engage in the transformation of content to make it intellectually accessible to learners. In addition, the use of improvised resources provided meaningful platforms to demystify abstract scientific phenomena in Life Sciences such as mitosis and meiosis. Clark and Mathis (2000) argue that the processes of mitosis and meiosis, while simple in nature, are conceptually difficult for the learners.

The availability of essential resources is a key requirement for provision of quality education for all. However, the South African basic education system is largely characterised by inequitable access to resources (Sedibe, 2011). In addition, a substantial number of schools in South Africa are still under-resourced. The provision of quality science education within the South African context is largely hampered by lack of essential resources. In support of this notion, Parker (2018) postulates that effective science teaching and learning requires the incorporation of instructional materials rather than undue reliance on traditional instructional methods which often stifle pedagogic innovation. 


\section{Conclusion}

The integration of improvised resources in science teaching and learning can serve as a powerful instructional mechanism to enhance scientific literacy in resource-constrained learning environments. There is a crucial need to implore teachers as key agents of educational change to fully embrace the use of improvised resources to enhance their professional growth through pedagogic innovation.

\section{References}

Clark, D.C. \& Mathis, P.M. (2000). Modeling Mitosis \& Meiosis: A Problem-Solving Activity. The American Biology Teacher, 62(3), 204-206.

Driscol, M.P. (2005). Psychology of Learning for Instruction. Publisher: Pearson

McCombs B. L. \& Whisler, J. S. (1997). The Learner-Centered Classroom and School: Strategy for Increasing Student Motivation and Achievement. San Francisco.

Parker, J., Osei-Himah, V. \& Asare, I. (2018). The effects of improvised materials on the study of science in basic schools in Aowin Municipality-Ghana. Research on Humanities and Social Sciences. ISSN 2224-5766.

Schweisfurth, M. (2011). Learner-centred education in developing country contexts: From solution to problem? International Journal of Educational Development, 31(5), 425-432.

Sedibe, M. (2011) Inequality of access to resources in previously disadvantaged South African high schools. Journal of Social Sciences, 28(2), 129-135. 